\title{
ORTELOVÉ KNIHY PRAŽSKÉHO APELAČNÍHO SOUDU A JEJICH INTERPRETACE*
}

\author{
JOSEF VACEK
}

\begin{abstract}
Book of Sentences of Appeal Court in Prague
This paper focuses on fundamental historical source important for recognition of judicial praxis in the early modern era: Books of Sentences of Appeal Court in Prag. This court was established in 1548 and since that year were the sentences taped down to books of sentences in two language rows: czech and german. The study analyzes both the outside of the source (font, language, graphical form of the decision) and, above all, its internal structure. At the same time, some particular requirements (which included each decision) are identified, and then the possibilities of their interpretation in individual and in context are presented. The paper is based on the knowledge of dozens of ortel books across the 250 year period for which the study is written. Its contribution lies mainly in describing some general elements that touch this source. The thesis can also serve as a basis for quantitative and qualitative research in the field of early modern justice.
\end{abstract}

Keywords: Appeal Court in Prague; juridical practice in early modern period; criminality; books of sentences; interpretation of legal history

Klíčová slova: Apelační soud v Praze; soudní praxe v raném novověku; kriminalita; ortelové knihy; interpretace v právních dějinách

DOI: $10.14712 / 23366478.2020 .5$

\section{PŘEHLED DOSAVADNÍHO BÁDÁNÍ}

Téma trestního soudnictví v období raného novověku není v české (právně) historické vědě nové, ${ }^{1}$ nicméně v posledních dekádách se objevuje se zvýšenou intenzitou a dostává se do středu zájmu nemalého počtu badatelů. ${ }^{2}$ Tato skutečnost již sama o sobě umožňuje jednak zkoumat danou problematiku z různých úhlů pohledu, jednak dosažené výsledky vzájemně srovnávat. Zatímco v 70. a 80. letech minulého století se

* Tato kapitola vychází z autorovy diplomové práce s názvem Constitutio Criminalis Josephina a jeho vliv na rozhodovací praxi Apelačního soudu: Sexuální delikty v letech 1687-1727, obhájené v červnu 2019 na Právnické fakultě Univerzity Karlovy, přičemž některé části jsou z ní přejaty.

1 Jeho počátky můžeme zařadit do 2. poloviny 19. století a spojit se jmény kulturních historiků Josefa Svátka či Zikmunda Wintera a Čeňka Zíbrta.

2 Svědčí o tom nejen zvýšené množství nových knih a odborných článků s tímto tématem, ale i nárůst diplomových prací; hlavní autoři budou uvedeni dále v textu. 
práce v oblasti dějin raně novověké kriminality zaměřovaly na městské (hrdelní) právo, smolné knihy a jejich zpřistupňování, ${ }^{3}$ došlo v posledním desetiletí minulého století k rozšíření využívaných pramenů a do popředí se dostaly nové přístupy a metody. ${ }^{4}$ Různé př́stupy k problematice hrdelního soudnictví vyústily na počátku tohoto století v diskuzi o postihu odlišného chování jednotlivců právě pro období raného novověku. ${ }^{5}$ V průběhu tohoto vývoje se pochopitelně setkáváme i s pracemi zastřešujícími - at' už se jedná o práce Jiř́ho Klaboucha ${ }^{6}$ již z 60 . let 20. století nebo pozdější práce Karla Malého na téma trestního práva. ${ }^{7}$

Od nového tisíciletí se pak setkáváme s různorodostí badatelských prrístupů k tématu trestního práva a trestního soudnictví v historii. Po desetiletích se znovu se objevují edice raně novověkých pramenů souvisejících s trestním právem, ${ }^{8}$ vznikají popisy kriminality na určitém území v kontextu každodenního života jeho obyvatel, ${ }^{9}$ zkoumá se kriminální chování konkrétních jednotlivců ${ }^{10}$ a pochopitelně vznikají i práce syntetické a přehledové. ${ }^{11}$

Jistým tmelícím prvkem stručně představeného rozmanitého výzkumu posledních dekád je role soudi̊, konkrétně pak soudu apelačního. Apelační soud jako instituce, a především pak i jeho rozhodnutí se objevují např́íc pracemi, a to bez ohledu na zvolený př́stup či metodu výzkumu. Jednotlivá rozhodnutí apelačního soudu se tak stala předmětem zájmu zejména v odborných studiích zaměřených na dějiny kriminality kon-

3 Zde je potřeba vyzdvihnout práce Jaroslava Pánka a Evy Procházkové.

$4 \mathrm{~V}$ tomto ohledu je možné vyzdvihnout zejména pokus o soupis pramenů a literatury k tématu hrdelního soudnictví českých zemí. FRANCEK, J. - ŠIMEK, T. Hrdelní soudnictví českých zemí: soupis pramenů a literatury. Zámrsk: Státní oblastní archiv Zámrsk, 1995.

5 Trojice textů byla otištěna v roce 2001 v druhém čísle časopisu pro kulturní dějiny (Kuděj), přičemž do ní svými výstupy přispěli HIML, P. „Odlišné chováni'“ v raném novověku - plaidoyer za odklon od státně-centristické a ,elitní“ perspektivy a za historicko-antropologický přístup, s. 53-60, TINKOVÁ, D. Úvahy nad problematikou ,trestního práva“a „hrdelního soudnictví"v historii a historiografii. Kuděj. Časopis pro kulturni dějiny, 2001, roč. 3, č. 2, s. 60-67, a tamtéž KREUZ, P. Aktéři bez hřiště a pravidel?, s. 68-76.

6 KLABOUCH, J. Staré české soudnictví: (jak se dřive soudivalo). Praha: Orbis, 1967.

7 Např. MALÝ, K. Trestní právo v Čechách v 15.-16. století. Praha: Univerzita Karlova, 1979.

8 Přímo k trestnímu právu KOUPIL, O. - KOUPILOVÁ M. - MALÝ, K. - ŠOUŠA, J. - ŠOUŠA, J. VOJTÍŠKOVÁ, J. - WOITSCHOVÁ, K. Prameny $k$ dějinám trestního práva v českých zemích v obdobi absolutismu: chrestomatie. Díl. I., Druhá polovina 17. a počátek 18. století. Praha: Karolinum, 2018. Rovněž lze uvést edici KREUZ, P. - MARTINOVSKÝ, I. Vladislavské zřizení zemské a navazujíci prameny: (Svatováclavská smlouva a Zřizení o ručnicích). Praha: Scriptorium, 2007, či MALÝ, K. - SOUKUP, L. - SKŘEJPKOVÁ, P. - ŠOUŠA, J. Práva méstská Království českého: edice s komentářem. Praha: Karolinum, 2013.

9 Např. ČECHURA, J. Kriminalita a každodennost v raném novověku: Jižni Čechy 1650-1770. Praha: Argo, 2008, či MATLAS, P. Shovívavá vrchnost a neukáznění poddani?: Hranice trestni disciplinace poddaného obyvatelstva na panství Hluboká nad Vltavou v 17.-18. století. Praha: Argo, 2011.

10 ČECHURA, J. Neklidnýživot obyčejné ženy: Johana Peřková (1703-1745). Praha: Nakladatelství Lidové noviny, 2013.

11 ADAMOVÁ, K. - RIEGROVÁ, B. - SKŘEJPKOVÁ, P. - SOUKUP, L. - ŠOUŠA, J. Dějiny českého soudnictví od počátkủ české státnosti do roku 1938. Praha: LexisNexis, 2005, ADAMOVÁ, K. - LOJEK, A. - SCHELlE, K. - TAUCHEN, J. Velké dějiny zemí Koruny české. Tematická rada, Právo. Praha: Paseka, 2017, FRANCEK, J. Velké dějiny zemi Koruny české. Tematická řada, Zločinnost a bezpráví. Praha: Paseka, 2011. 
krétní lokality, ${ }^{12}$ resp. panství13 či v případových studiích, věnujících se jednotlivým aktérům, ${ }^{14}$ výjimečně pak samostatnému deliktu. ${ }^{15}$

Práce tohoto druhu jsou přínosné především díky tomu, že pomáhají pochopit, jak apelační soud mohl realizovat svá oprávnění v konkrétních př́ípadech, komplexní pohled však logicky chybí, ${ }^{16}$ nebot' předmětem zkoumání bývá jedna kriminální kauza, př́padně rozhodování na určitém území, avšak zpravidla bez obecně použitelných výsledků. ${ }^{17}$ Pracemi ležícími na tomto pomezí jsou pak studie věnované př́mo rozhodnutím apelačního soudu, avšak pro vymezené území. ${ }^{18}$ Nemalá část z těchto prací je pak věnována především období do poloviny 17 . století, pozornost je tedy soustředěna především na první století od zř́zení soudu. ${ }^{19} \mathrm{~K}$ tomu, daný výzkum mohl být rozvíjen nejen kvantitativně, ale i kvalitativně, je třeba postihnout některé aspekty a náležitosti vydávaných rozhodnutí. Na otázku, kde leží možnosti a meze interpretace, se pak v některých ohledech pokouší odpovědět tato práce, a sice tak, že analyzuje typový obsah rozhodnutí a všímá si jednotlivých prvkủ, které jsou následně představeny a posléze rozebrány.

Apelačnímu soudu nebyla dosud věnována, i přes význam této instituce, patřičná pozornost, a tím spíše to pak platí o jeho rozhodovací praxi. Dějinám instituce se věnoval Václav Zdeněk ve své práci z roku 1933 s názvem Dějiny královského appellačního soudu na hradě Pražském, kde mimo jiné uvedl i přehled prezidentů a viceprezidentů

12 V poslední době například FRANCEK, J. Zločin a trest v Pardubicich 16.-18. století. Ústí nad Orlicí: Oftis, 2011. Pro dobu pobělohorskou je cenným př́íspěvkem rovněž studie o komunikaci apelačního soudu se soudem královského města Loun, kterou zpracovaly NEUDERTOVÁ, M. - KUTHANOVÁ, L. Ke komunikaci apelačního soudu a městských hrdelních soudů v době pobělohorské. In: FRANCEK, J. (ed.). Hrdelní soudnictví českých zemi 16.-18. století. Sbornik přispěvki̊ z konference konané v Pardubicich 21.-22. 9. 1995. Pardubice: Východočeské muzeum v Pardubicích, 1996, s. 119-132.

13 Dvě cenné studie, které společně sepsaly RŮŽIČKOVÁ, R. - SIGLOVÁ, T. Apelační soud a odvolání proti rozhodnutím nižších soudů pardubického panství. Př́ípady řešené v civilním soudním rrízení v 16.-18. století. Sborník prací východočeských archivů. Zámrsk: Státní oblastní archiv v Zámrsku, 2009, roč. 13, s. 13-130 a RŮŽIČKOVÁ, R. - SIGLOVÁ, T. Apelační soud a případy řešené v inkvizičním soudním řízení na pardubickém panství v 16.-18. století. Sborník prací východočeských archivů. Zámrsk: Státní oblastní archiv v Zámrsku, 2010, roč. 14, s. 13-110.

14 Např́klad RICHTER, D. Chrudimský měšt’an Vít Hořínek a jeho pozůstalost z roku 1588 před pražským apelačním soudem. Chrudimské vlastivědné listy, 2006, roč. 24, č. 6, s. 10-11.

15 PROCHÁZKOVÁ, E. Perzekuce romských kočovníků v českých zemích v 18. století. (Na základě rozboru ortelních manuálů pražského apelačního soudu.). Sborník archivnich prací. Praha: Ministerstvo vnitra, 1992, roč. 42, č. 2, s. 307-409.

16 Pokusem o prolomení této hradby je pak autorův článek VACEK, J. Proměny praxe apelačního soudu po přijetí josefínského hrdelního řádu: trestání incestu v letech 1687-1727. Právněhistorické studie, 2017, roč. 47, č. 2, s. 18-32, a rovněž jeho výše uvedená diplomová práce.

17 Daniela Tinková pak mluví o „relativně úzkém zajetí regionálně orientovaných studii ,kriminality “, TINKOVÁ, c. d., s. 60.

18 Viz např́ílad HAUBERTOVÁ, K. Loketsko v ortelních manuálech apelačního soudu v letech 1548-1740. K zániku chebské oblasti městského práva v roce 1548. Sbornik Chebského muzea. Cheb: Krajské muzeum Cheb, 2006, s. 8-22.

19 Zcela zjevně dokládá tuto skutečnost KINDL, J. Zápisy v ortelních manuálech apelačního soudu z let 1548-1648 týkající se poddanského města Skutče. In: KUDRNOVÁ, J. - POLEHLA, P. - SEVERA, M. Ad honorem VN: $k$ 65. narozeninám Věry Němečkové připravili vděčni prátelé, kolegové a studenti. Hradec Králové: Hradecká studentská sekce České archivní společnosti, 2015, s. 211-225, či rovněž KINDL, J. Královéhradecké soudní pře z let 1548-1564 postoupené k apelačnímu soudu. Východočeský sborník historický. Pardubice: Východočeské muzeum v Pardubicích, 2017, sv. 31, s. 105-132. 
soudu. ${ }^{20}$ Za zásadní počin k poznání dějin apelačního soudu jakožto instituce je nutno považovat taktéž práci J. F. Schmidta s názvem Monographie des kaiserl. königl. Böhm. Appellations-Gerichtes již z roku $1850 .{ }^{21}$ Svým obsahem se v zásadě jedná o komentovanou pramennou edici, ve které jsou čtenáři zpř́stupněna originální znění dokumentů, které př́imo ovlivnily fungování či samotný vznik soudu, uvedeny jsou také přehledy počtu případů za některé roky, nejstarší soudní rozhodnutí a podobně. Cenný je rovněž přehled personálního obsazení soudu. Dějiny apelačního soudu do roku 1644 zachytil ve své diplomové práci taktéž pozdější archivář Ivo Plecháček, ${ }^{22}$ který však bývá opomíjen. ${ }^{23}$

K personálnímu obsazení apelačního soudu je pak možné využít rovněž přehled zpracovaný Klárou Woitschovou, ${ }^{24} \mathrm{k}$ němuž je třeba připočítat i dílčí studie, které vypracovala na témata související s rozhodovací praxí apelačního soudu. ${ }^{25}$ Pro starší období je možné zmínit rovněž studii Jaroslavy Hausenblasové, která se věnovala obsazení apelačního soudu od jeho vzniku do roku 1627.26 Organizaci a fungování soudu se v dílčích studiích věnovali také Karolina Adamová (pro období do roku 1651) 27 či Boris Šalak (zejména pro období po roce 1740). ${ }^{28}$

Soustavnou pozornost činnosti apelačního soudu kolem roku 1700 věnuje v současnosti Daniel Wojtucki, polský historik působící na Historickém institutu vratislavské

20 ZDENĚK, V. Dějiny král. appellačního soudu na Hradě pražském, nyní Vrchního soudu v Praze od roku 1548-1933. Praha: 1933.

21 SCHMIDT, J. F. Monographie des kaiserl. königl. Böhm. Appellations-Gerichtes seit dessen Errichtung als Appellationskammer in dem Jahre 1548 bis zu dessen im Jahre 1850 erfolgter Umwandlung in das kais. kön. Oberlandesgericht des zu dem constitutionellen Kaiserthume Oesterreich gehörigen Kronlandes Böhmen. Praha: Jeřábek, 1850.

22 PLECHÁČEK, I. Apelační soud v Čechách do roku 1644. Diplomová práce. Filozofická fakulta: Univerzita Karlova, 1956.

23 KREUZ, P. Das Appellationsgericht in Prag 1548-1783. Bisherige Forschung, erhaltene Quellen und historische Entwicklung. In: AUER, L. - ORTLIEB, E. - FRANKE, E. In letzter Instanz. Appellation und Revision im Europa der Frühen Neuzeit. [= Beiträge zur Rechtsgeschichte Österreichs]. Vídeň: Österreichische Akademie der Wissenschaften 2013, Band 1, s. 231-250.

24 WOITSCHOVÁ, K. Personální obsazeni pražského apelačního soudu v letech 1548-1783: ,,--což slušného a spravedlivého jest fedrovati-- “. Pelhřimov: Nová tiskárna Pelhřimov, 2010. K tomu však rozsáhlá kritická recenze MAREŠ, P. Paginae historiae: sborník Národního archivu. Praha: Národní archiv, 2016, roč. 20 , č. 1 , s. $387-401$.

25 Krom výše citovaného článku o činnosti apelačního soudu v letech 1672-1682 viz též WOITSCHOVÁ, K. Ortelní manuály a knihy protokolů apelačního soudu v Praze z let 1548-1783. Paginae historiae: sborník Národního archivu. Praha: Národní archiv, 2008, roč. 16, s. 545-558, a také WOITSCHOVÁ, K. Edice nebo databáze?: ortelní manuály jako komplementární pramen k poznání raně novověkého městského soudnictví. In: SULITKOVÁ, L. (ed.). Stav a perspektivy zpřistupňování středověkých a raně novověkých městských knih. Ústí nad Labem: Filozofická fakulta Univerzity Jana Evangelisty Purkyně v Ústí nad Labem, 2010, s. 241-252. Zejména pak k poslednímu titulu je však třeba uvést oprávněnou kritiku, kterou ke stavu autorčina výzkumu snesl KREUZ, P. Dějiny pozdně středověkého a raně novověkého městského soudnictví v českých zemích v české historiografii posledních dvaceti let. In: FEJTOVÁ, O. - HRUBÁ, M. - LEDVINKA, V. - PEŠEK, J. - SULITKOVÁ, L. Města ve středověku a raném novověku jako badatelské téma poslednich dvou desetiletí: stati a rozšiřené př́spěvky z 30. vědecké konference Archivu hlavniho města Prahy, uspořádané ve dnech 11. a 12. října v Clam-Gallasově paláci v Praze. Dolní Břežany: Scriptorium, 2013, s. 179-199, zde s. 196-197.

26 HAUSENBLASOVÁ, J. Počátky apelačního soudu v Čechách a jeho personální obsazení 1548-1627. Paginae historiae: sborník Národního archivu. Praha: Národní archiv, 2005, roč. 13, s. 5-31.

27 ADAMOVÁ, Apelační soud, s. 101-112.

28 ŠALAK, B. Organizace a působnost apelačního soudu v Praze v době tereziánské. Sborník archivních prací. Praha: Ministerstvo vnitra, 2013, roč. 63, č. 1, s. 66-130 a ŠALAK, B. Všeobecný apelační soud v Praze. Právněhistorické studie. Praha: Karolinum, 2014, sv. 44, č. 1, s. 80-111. 
univerzity. Kromě dvojice článků, ve kterých se věnuje konkrétním rozhodnutím apelačního soudu v určité lokalitě (Jelení Hora a Slavkov u Brna), ${ }^{29}$ napsal Wojtucki i studii zabývající se komunikací soudu s městy ve Slezsku. Práce postihuje celé období, po které Slezsko spadalo pod jurisdikci soudu (1548-1740). Wojtucki zde rovněž uvádí typy dokumentů, které mezi Prahou a slezskými městy kolovaly, čímž přináší doklady o činnosti apelačního soudu. ${ }^{30}$ Obdobně aktivní pak byl i Lubomír Novotný s dvojicí studií ze 17. století dotýkajících se apelačního soudu. ${ }^{31}$

Dějinám kriminality, soudnictví a ortelovým knihám apelačního soudu zvlášt', se ve svých studiích hojně věnoval též Petr Kreuz. Těžiště Kreuzových prací leží především v předbělohorském období, autor nicméně snesl množství poznatků rovněž pro období následující. Dosažená zjištění tvoří cenné podklady pro další studium kriminality a fungování soudnictví v raném novověku, a to i díky tomu, že se vyznačují dlouhodobě důslednou archivní prací a přesným užíváním dobové právní terminologie. ${ }^{32}$

\section{ORTELOVÉ KNIHY APELAČNÍHO SOUDU}

Klíčovým pramenem pro poznání rozhodovací praxe apelačního soudu jsou knihy obsahující jednotlivá soudní rozhodnutí. Knihy rozhodnutí jsou uloženy v Národním archivu v Praze v rámci 1. oddělení (Oddělení fondů samosprávy a státní správy do roku 1848 a církevních institucí) ve fondu Apelační soud v Praze 1548-1783 (1788). ${ }^{33}$ Při jejich pojmenování vzniká určitý terminologický problém, obecně však lze (byt's jistými výhradami) přijmout označení „ortelové knihy“. Knihy byly vedeny ve dvou řadách, totiž české a německé, přičemž názvy knih a jejich obsah kolísaly jednak dle řady a jednak dle období, ve kterém byly psány; v tomto ohledu je pak zásadní, že

29 WOJTUCKI, D. Wyroki Praskiej Izby Apelacyjnej w sprawach kryminalnych dla sądu w Slavkově u Brna w I połowie XVIII wieku. Anthropologia integra, 2017, sv. 8, č. 2, s. 37-42, a WOJTUCKI, D. Wyroki Praskiej Izby Apelacyjnej w sprawach kryminalnych dla sądu w Jeleniej Górze w II połowie XVII i w I połowie XVIII wieku. Rocznik Jeleniogórsk, 2016, tom. XLVIII, s. 51-64.

30 WOJTUCKI, D. Korespondencja Praskiej Izby Apelacyjnej z miastami na Śląsku w latach 1548-1740. KLIO. Czasopismo poświęcone dziejom Polski i powszechnym, 2012, Vol. 23, No. 4, s. 167-175, zde zejm. s. $170-171$.

31 NOVOTNÝ, L. Kauza „Abeles“. Př́́klad řízení v trestní věci před apelačním soudem na sklonku 17. století. In: KRUŠÍNSKÝ, R. (ed.). Problematika historických a vzácných knižních fondů Čech, Moravy a Slezska: sborník z 17. odborné konference Olomouc, 5.-6. listopadu 2008. Olomouc: Vědecká knihovna v Olomouci et al., 2009, s. 199-225, a KRUŠíNSKÝ, R. Apelační soud ve 2. polovině 17. století. (Vliv instrukcí Ferdinanda III. z roku 1644 na činnost apelačního soudu). In: KRUŠ́́NSKÝ, R. (ed.). Problematika historických a vzácných knižních fondi̊ Čech, Moravy a Slezska: sborník z 20. odborné konference Olomouc, 20.-21. zárí 2011. Olomouc: Vědecká knihovna v Olomouci et al., 2012, s. 47-55.

32 KREUZ, P. Dějiny pozdně středověkého a raně novověkého městského soudnictví v českých zemích v české historiografii posledních dvaceti let. In: Města ve stredověku a raném novověku jako badatelské téma poslednich dvou desetiletí: stati a rozšírené přispěvky z 30. vědecké konference Archivu hlavního města Prahy, uspořádané ve dnech 11. a 12. října v Clam-Gallasově paláci v Praze. Dolní Břežany : Scriptorium, 2013, s. 179-199, a analýzy téhož autora: K možnostem využití knih protokolů a německých prezidentských register pražského apelačního soudu ke studiu soudnictví v Kladsku v době předbělohorské. Kladský sborník. Trutnov: Lupus, 2016, roč. 11, s. 115-143, a dále z již rovněž zmíněného zásadního článku Das Appellationsgericht in Prag 1548-1783 a dalších dílčích studií, vztahujících se zejména k předbělohorskému soudnictví.

33 K obsahu fondu blíže KŘEPELKOVÁ, A. Apelační soud v Praze, 1548-1783 (1788), inventár. Praha: Národní archiv, 1964. 
ortelové knihy pokrývají takřka bez mezer celé období let 1548-1783. Petr Kreuz pak všechny tyto knihy označuje jako konceptní registra, ${ }^{34}$ která jsou rozdílná od čtyř českých a pěti německých knih čistopisủ, ${ }^{35}$ takzvaných prezidentských register, které se dochovaly pro roky 1548-1566 (české), resp. 1548-1570 (německé). ${ }^{36}$

Ačkoli inventář $\mathrm{k}$ fondu Apelační soud $\mathrm{v}$ Praze uvádí, že $\mathrm{v}$ př́ípadě české řady knih vedených do roku 1681 se jedná o příruční knihy, pro které platí, že v nich ,jsou zápisy vedeny zběžným nedbalým pismem s častými škrty a opravami, jež nasvědčují tomu, že se jedná o prozatímní zápisy, sloužící jako podklad k dalšímu jednáni" ${ }^{\prime 37}$ nelze se s tímto závěrem ztotožnit. Předně je třeba uvést, že autorka tímto popisem shrnuje stav více než čtyř desítek knih ${ }^{38}$ pro období let 1548-1681, přičemž se nabízí podezření, že jejich obsah se za takto dlouhé období mohl proměnit. Nelze totiž přehlédnout, že např́ílad poslední dvě knihy spadající do takto vymezeného období3 ${ }^{39}$ uvedené charakteristice rozhodně neodpovídají. Jsou psány úhledně, bez úprav či častých škrtů (resp. chybovost v těchto knihách se nikterak neliší od množství chyb obsažených v knihách vzniklých po roce 1681). Jakkoli tedy knihy vedené od roku 1682 skutečně přijímají název „Ortelové a naučení" namísto dosavadního pojmenování „Manuál ortelní", neliší se způsobem vedení a je otázkou, zda se od sebe liší svým obsahem. ${ }^{40}$

Stran názvu knih je třeba uvést, že nebyl ustálen a jednotlivé svazky nesly vlastní název. V české řadě knih se přitom nejčastěji objevuje nadpis „Ortele a Naučení na Rok", přičemž následně jsou uvedeny roky, pro které je daná kniha vedena, prrípadně je název zkrácen pouze na „Ortele na Rok“, od roku 1722 jsou pak knihy nazvány jako „Český Ortele na Rok" ${ }^{41}$ či „Ortele Český Na Rok"42. U řady německých knih je situace obdobná české řadě - knihy byly nadepisovány jako „Orthel vnd Belehrnung [en] " a doplněny výčtem let, pro která jsou v nich zápisy vedeny. ${ }^{43} \mathrm{Od}$ roku $1705^{44}$ pak v nadpisech nechybí údaj o tom, že se jedná o knihu německou, od roku $1714^{45}$ se pak název omezuje pouze na ortely (Urthel), nebot' naučení (Belehrnungen) se již v názvu neobjevují.

Podobou, jakou byla rozhodnutí do knih zapisována, se jednotlivé řady neliší, a proto je možné o nich pojednat souhrnně, stejně tak se to týká i jejich stránkového rozsahu, vedení rejstříků, případně dalších znakủ a náležitostí. Jelikož je zde popsána podoba

34 Národní archiv v Praze, fond Apelační soud v Praze, 1548-1783 (1788), inv. č. 102-182 a 184-280. Dále je pro označení tohoto fondu uživána zkratka „AS“. Ortelové knihy jsou označovány pouze dle inventárního čísla.

35 AS, inv. č. 96-99 a 281-285.

36 KREUZ, P. K možnostem využití knih protokoli̊, s. 115-116.

37 Ǩ̌EPELKOVÁ, A. Apelačni soud v Praze, s. 5.

38 AS, inv. č. 102-142, př́ípadně lze zahrnout rovněž inv. č. 96-101.

39 AS, inv. č. 141 a 142 vedené pro roky $1658-1681$.

$40 \mathrm{~K}$ této otázce nebyl dosud proveden žádný výzkum. Jediným, kdo se zevrubně zabýval knihami apelačního soudu na přelomu těchto období, byla Klára Woitschová, která však rozdílné označení knih pouze zmiňuje, avšak nezkoumá důvod dané změny a nazývá je souhrnně „knihy ortelů a naučeni““. Viz WOITSCHOVÁ, K. Obraz činnosti pražského apelačního soudu v letech 1672-1682 ve světle ortelních manuálů a knih protokolů. Paginae historiae: sborník Národního archivu. Praha: Národní archiv, 2011, roč. 19, s. 97-115, zde s. 100.

41 AS, inv. č. 154, 155, 157-159.

42 AS, inv. č. 156.

43 Srov. AS, inv. č. 260 a 261.

44 AS, inv. č. 266.

45 AS, inv. č. 268. 
zápisů z knih, které byly vedeny takřka 250 let, jde nutně o popis orientační, většinový, avšak pochopitelně se na různých místech objevují tu větší, tu menší odchylky. K uvedenému popisu je rovněž nutno uvést, že se týká především trestních věcí. Ačkoli základní popis bude shodný i pro rozhodnutí v civilních věcech, nelze popis zde uvedený bez dalšího přjejímat.

\section{PODOBA ROZHODNUTÍ APELAČNÍHO SOUDU}

Jednotlivá rozhodnutí apelačního soudu obsažená v ortelových knihách jsou nadepsána místem, kam jsou soudem posílána, tedy místem, ze kterého bylo odesláno odvolání, žádost o naučení a podobně. Zde je potřeba „místem“ rozumět rovněž instituce a někdy též soukromé osoby, kterým bylo rozhodnutí adresováno. Předně se tedy jedná o města a městečka, může však jít i o právnické osoby, př́padně majitele panství či jiné osoby. Skupinu těchto „míst“ je těžké úžeji vymezit, a to jak z hlediska osobního, tak i z hlediska geografického, nebot' navzdory působnosti na země Koruny české (Čechy, Moravu a Slezsko, do roku 1635 taktéž obojí Lužici) směřovala některá rozhodnutí apelačního soudu i za hranice těchto zemí. ${ }^{46}$

Po levé straně, v marginálii, vertikálně pod úrovní nadepsaného místa, je uvedeno jméno soudce-referenta. Ten měl věc zpracovat a připravit k rozhodnutí, o kterém následně hlasovali ostatní soudci. Dosud nebylo zjištěno, do jaké míry měl tento referent vliv na rozhodnutí ve věci samé. K zodpovězení této otázky by bylo nutné využít dalších archivních pramenů z jiných fondů, než je Apelační soud v Praze. Tato otázka je komplexní; bude nutné nashromáždit ještě větší množství materiálu, např́klad korespondence jednotlivých soudců či advokátů.

Samotný text rozhodnutí je uvozen zdůvodněním, z jakého titulu je vydáváno - tento úvod má formulářový charakter, který bývá dodržován napříč knihou. Úvody jsou tak různé „Jménem a na mistě Praesident, Vice Praesident a Raddy“, dále „Jménem a na místě Praesident a Raddy“, v průběhu 18. století pak byla i tato krátká formule krácena na pouhé „Jménem a na mistěc، V německé verzi se pak lze nejčastěji setkat s návětím „In Nahmen“. Na tomto místě je vhodné pro srovnání uvést, že v 16. století byla rozhodnutí vydávána prímo z titulu panovníka, a začínala tak např. slovy „My Maximilián etc. “. ${ }^{47}$ Lze tedy sledovat zdánlivou proměnu v chápání toho, z jaké, resp. čí moci je rozhodnutí činěno. 48

Rozhodnutí dále obsahuje stručné označení odesílajícího práva či vrchnosti (tedy místa, které žádá o naučení, ortel), případně jiné osoby, poté jméno odsouzence (v pří-

46 Ke stejnému závěru pro předbělohorské období dospívá a za překvapivý jej označuje KREUZ, K možnostem využití knih, s. 117, včetně poznámek tam uvedených.

47 Srov. např. AS, inv. č. 115.

$48 \mathrm{~K}$ tomu srov. zakládací instrukci z 20. ledna 1548: „daß Urtheil in Anfang dermaßen verfaßen und ausgehen lassen wie der articul folget" citováno dle SCHMIDT, c. d., s. 44, srov. též s. 7 a dále ADAMOVÁ, K. Apelační soud v Českém království v letech 1548-1651. In: MALÝ, K. (ed.). Collectanea opusculorum ad iuris historiam spectantium Venceslao Vaněček septuagenario ab amicis discipulisque oblata $=$ Pocta akademiku Václavu Vaněčkovi k 70. narozeninám. Praha: Univerzita Karlova, 1975, s. 101-112, zde s. 104. V pozdější době je explicitní, že rozhodnutí vydává soud, který supluje vůli panovníka. 
padě civilních věcí jsou uvedena jména sporných stran) a označení věci, pro kterou byl dotyčný odsouzen (či předmět právní pře). Věc v trestních př́padech bývá uvedena latinským výrazem, např́klad „,adulterium“ či „,homicidium“, není to však bezvýjimečné a mnohdy se lze setkat s označením českým či německým, $v$ civilních záležitostech je pak terminologie odvislá od konkrétní věci. Informace o skutku bývá doplněna (zejména v českých knihách) rovněž o údaj, zda byl výslech dobrovolný či útrpný. V závěru rozhodnutí je uveden výrok v dané věci (povětšinou odsuzující) a je zakončeno slovy „Podle práva“ resp. „Von Rechts Wegen“" (někdy zkracováno na P.P., resp. V.R.W.) a datem vydání rozhodnutí.

Zvláště u rozhodnutí zaznamenaných v českých řadách nebylo neobvyklé, že po nich následovala misíva (missiv), přípis právu, kterému bylo adresováno rozhodnutí. V tomto př́íisu stanovoval apelační soud zpravidla další postup nižšího práva, určoval některé detaily vykonání uloženého trestu či dané právo napomínal pro nedodržení předepsaného formálního postupu. Tyto př́ípisy jsou poměrně cenným materiálem pro poznání dobové soudní praxe, nebot při správné interpretaci umožňují seznat, jaké otázky apelační soud řešil a jak - rovněž pak lze naopak rozpoznat, které otázky a témata zůstaly mimo pozornost soudu.

Ortelové knihy nejsou vedeny striktně chronologicky. Zdá se, že alespoň jednotlivé zápisy byly doplňovány po určitém čase od vynesení rozhodnutí (například během týdne), nebot' se zpravidla stává, že rozhodnutí s dř́vějším datem je zapsáno až po rozhodnutí s datem pozdějším, a řada tak není čistě chronologická. Uvedený asynchronní postup však nikterak nenarušuje bádání, nebot' se jedná o posuny v rámci několika dní či týdnů, zcela výjimečně měsíců, chronologická posloupnost měsíců je pak v zásadě dodržována.

Ohledně stránkového rozsahu knih lze konstatovat, že sestávají ze stovek stran, přičemž nejužší knihy mají kolem jednoho sta popsaných stran, ${ }^{49}$ zatímco knihy s nejvyšším počtem listů mají i přes pět stovek folií. ${ }^{50}$ Rejstříky jsou ve všech případech uvedeny na konci knih, přičemž zpravidla jsou trojího charakteru: místní, jmenné a věcné a u každého hesla je odkázáno na př́slušné folium. Jazyk místního a jmenného rejstř́ku se odvíjí především od toho, v jaké jazykové řadě se kniha nachází, věcný rejstř́ik pak bývá veden latinsky. Věcný rejstř́k je povětšinou veden odděleně od rejstř́kủ místního a jmenného.

Stran jazyka, kterým byla rozhodnutí psána, je možné konstatovat, že zatímco knihy německé řady jsou zásadně vedeny německy, pro českou řadu toto konstatování platí jen po část období, nebot' ke konci fungování apelačního soudu (zhruba v posledních pěti dekádách) byla česká řada vedena mnohdy v němčině a její označení ,„̌eská“ tak lze dovozovat spíše ze zeměpisného rozložení míst, kam rozhodnutí mířila. ${ }^{51} \mathrm{Z}$ uvedeného pravidla však nacházíme výjimky, kdy některá rozhodnutí v německých knihách jsou psaná česky, a naopak, některá rozhodnutí v knihách české řady jsou psaná německy,

\footnotetext{
49 Např. kniha AS, inv. č. 153 má 109 popsaných foliovaných stran a k tomu rejstř́ik na 39 nefoliovaných stran.

50 Např. kniha AS, inv. č. 272, která obsahuje 449 označených folií a dalších 66 nečíslovaných popsaných stránek rejstříku. Prohlédnutím knihy bylo navíc zjištěno, že patrně tři stránky (na přechodu mezi rozhodnutími a rejstř́ikem) byly vyříznuty.

51 Srov. např. KREUZ, Das Appellationsgericht, s. 238.
} 
př́ipadně nastává situace, kdy rozhodnutí je psáno jedním jazykem a misíva (je-li přiložena) je psána jazykem druhým. ${ }^{52}$

\section{NÁLEŽITOSTI JEDNOTLIVÝCH ROZHODNUTÍ}

Jednotlivá rozhodnutí apelačního soudu se skládala z řady typových, proměnlivých náležitostí. Ty lze, pomineme-li náležitosti vnější úpravy, jako je jazyk, písmo či množství písařem provedených oprav, rozčlenit do hlavních kategorií dle (a) místa, kam rozhodnutí směřovalo, (b) typu kauzy, (c) soudce-referenta a (d) data vydání rozhodnutí.

\section{AD (A) MÍSTO, KAM ROZHODNUTÍ SMĚŘOVALO}

Jak bylo naznačeno výše, v samém nadpisu rozhodnutí bylo uvedeno místo, z něhož bylo odvolání k apelačnímu soudu doručováno a kam následně byl doručován originál rozhodnutí apelačního soudu. Samotný výraz „místo“ je třeba vnímat v co nejširším slova smyslu a lze jej do jisté míry ztotožnit s pojmem „právo“ ve smyslu nositele soudní pravomoci. Jednalo se totiž vedle konkrétní obce (at' už města či městečka, což byla nejčastější varianta) též o jednotlivé fyzické, popřípadě též právnické osoby. Fyzickými osobami bývali většinou majitelé jednotlivých panství, v prrípadě Těšínska se mohlo jednat i o hejtmana tohoto knížectví. ${ }^{53}$ Mezi osoby právnické lze zahrnout některé úřady obdařené soudní pravomocí, přičemž z praxe známe např́klad rychtu pražského židovstva, ${ }^{54}$ vinařský cech v Těšíně ${ }^{55}$ a další. Specifikace zeměpisného určení mohla být upřesněna $\mathrm{v}$ textu samotného rozhodnutí, když bylo doplněno, v které zemi odesílající právo leží. Od místa, kterému bylo zasíláno rozhodnutí, je třeba rozlišovat místo, kam byla zasílána misíva. Ta totiž mohla směřovat jinam, a sice zejména majiteli panství, na kterém leželo odesílající právo, ${ }^{56}$ či např́klad krajskému hejtmanovi. ${ }^{57}$

\section{AD (B) TYP KAUZY}

Rozhodnutí lze dělit do dvou základních skupin, a to podle toho, zda se jednalo o kauzu trestní, nebo civilní. Oba typy kauz mají svá specifika, která je třeba při interpretaci zohlednit. Předně jde o označení stran, které ve věci figurují. V trestních věcech není obžalovaný (a ve fázi řízení před apelačním soudem rovněž nepravomocně odsouzený, nebot' př́ípady, kdy byl obžalovaný zproštěn viny, se před apelační soud nemohly dostat)

\footnotetext{
52 Srov. VACEK, Proměny praxe, s. 20. K tomu též HAUBERTOVÁ, K. Loketsko v ortelních manuálech apelačního soudu v letech 1548-1740. K zániku chebské oblasti městského práva po roce 1548. Sborník Společnosti pro výzkum kamenných křižů: výběr z prací členů a přátel společnosti. Aš: Muzeum Aš, 2008, s. 89-99, zde s. 97, pozn. 10.

53 AS, inv. č. 142 , fol. 10 .

54 AS, inv. č. 142 , fol. 33 .

55 AS, inv. č. 147 , fol. 9.

56 Např. AS, inv. č. 147, fol. 152.

57 Napřr. AS, inv. č. 144, fol. 82.
} 
nikterak specificky označován; že se jedná o člověka, který je trestně stíhán, lze seznat ze skutečnosti, že je v souvislosti s jeho jménem uveden skutek, ze kterého je obžalován a rovněž je nad ním vynesen rozsudek. Stranou, která plní v daném ř́zení roli žalobce, je odesílající právo, tedy to, které vyneslo prvostupňový odsuzující rozsudek.

Naproti tomu v civilních kauzách je označení stran v rozhodnutích jasně uvedené. Žalobce, jako jedna strana, je označený slovem původ či apelát a na druhé straně žalovaný, označovaný jako obžalovaný nebo apelant. Takto strany vystupovaly jak v prvostupňovém řízení, tak i v řizení před apelačním soudem, kde ovšem bývalo současně uvedeno, která ze stran podala opravný prostředek - tato strana je pak označována také jako odpůrce.

\section{AD (C) SOUDCE-REFERENT}

Úlohou soudce-referenta bylo připravit shrnutí kauzy pro ostatní tak, aby na základě tohoto shrnutí mohli soudci rozhodnout hlasováním v dané věci. Jméno tohoto soudce je vždy uvedeno v marginálii po straně rozhodnutí, což dovoluje sledovat přehled kauz, které zpracovával. V této oblasti je nutné provést důkladný výzkum, nebot' role a vliv soudců-referentů na rozhodnutí nebyly dosud takřka vůbec zkoumány, nicméně po prvních průzkumech lze předestřít tezi, že soudci nebyli specializovaní na určité typy kauz (napríklad že by konkrétní soudce dostával především případy usmrcení či krádeže $\mathrm{v}$ trestních věcech a dědické spory v civilních věcech). Rovněž je možné předpokládat, že prriřazení soudců-referentů $\mathrm{k}$ jednotlivým př́padům bylo ovlivněno jejich jazykovou vybaveností a $\mathrm{z}$ tohoto důvodu se s některými jmény setkáváme pouze $\mathrm{v}$ řadě české, nebo německé. Pro zkoumání jednotlivých rozhodnutí, jejich obsahu a následné interpretaci se může stát postava soudce-referenta důležitou právě tehdy, budeme-li znát širší kontext toho, jaký měla tato funkce vliv na rozhodovací praxi.

\section{AD (D) DATUM VYDÁNÍ ROZHODNUTÍ}

Po vynesení rozhodnutí měla být vyhotovena jejich písemná verze, která se jednak v opisu zaznamenávala do ortelových knih, jednak originál takto vyhotoveného rozhodnutí byl odesílán právu, od kterého podání prrišlo. Ačkoli byly v předpisech upravujících fungování soudu stanoveny lhůty pro vyřizování věcí, praxe ukazuje, že tyto nebyly vždy respektovány a př́pady se mohly táhnout i několik měsíců, zatímco jiné byly vyřizovány $\mathrm{v}$ řádu dnů. Tuto skutečnost mohou objasnit misívy jednotlivých rozhodnutí, nebot' některé uvádí datum, kdy apelační soud odvolání přijal a případně další informace stran délky trvání př́ípadu. Spolu s datem vydání rozhodnutí pak lze sestavit alespoň jednoduchou časovou osu, ze které lze dovodit trvání řízení před apelačním soudem. Spolu s materiály městských či dalších archivů je možné rekonstruovat průběh celé kauzy z časového hlediska. 


\section{ZÁVĚREM}

Téma apelačního soudu a zkoumání jeho rozhodovací praxe není samo o sobě nové. Navzdory této skutečnosti však stále chybí komplexnější práce, které by se věnovaly jednotlivým aspektům soudních rozhodnutí či odpovídajícím způsobem shrnuly vývoj této instituce nejen po stránce personálního obsazení nebo právních předpisů upravujících její strukturu a chod, nýbrž také po stránce rozhodovací. Cílem této práce je proto nastínit možnosti a meze interpretace klíčového pramene pro poznání rozhodovací praxe apelačního soudu, totiž ortelových knih pražského apelačního soudu.

Současná historiografie se soustředí především na samotné výroky rozhodnutí apelačního soudu, okolnosti jejich vydání však již nejsou v centru pozornosti, stejně jako jejich jednotlivé obsahové náležitosti. Jejich určení je přitom zásadní pro pochopení toho, jak soudní rozhodnutí vznikala a jaké údaje, krom samotného výroku o vině či při, obsahovala. Na základě analýzy stovek rozhodnutí pak bylo možné určit náležitosti, které obsahuje většina rozhodnutí, tedy typové znaky rozhodnutí. Těmi jsou: místo, kam bylo rozhodnutí apelačního soudu po jeho vynesení adresováno, typ kauzy, osoba soudce-referenta a datum vydání.

Předestřené znaky a možnosti jejich interpretace lze zvolit jako východisko kvantitativních i kvalitativních (popř́padě kvantitativně-kvalitativních) výzkumů, a to nejen ve vztahu k rozhodovací praxi apelačního soudu, nýbrž (byt's jistými obměnami) i soudů dalších. Tím lze následně využít dosažených výsledků i pro komparativní analýzy. Správné pochopení role jednotlivých náležitostí umožní lépe interpretovat celkové vyznění rozhodnutí, a to jak v konkrétních př́ípadech, tak celkově ve vztahu $\mathrm{k}$ úloze a postavení, které měl apelační soud ve struktuře soudnictví raného novověku.

Prohloubení tohoto výzkumu po stránce metodologické se nabízí v rovině vnější úpravy ortelových knih, kde bude sledováno zejména písmo, jazyk, členění, ale i počet stran, ze kterých se kniha skládá, její vnitřní členění, popřípadě př́ípisy na přídeští a podobně. Jakkoli se zdá, že uvedené náležitosti spadají spíše do oboru archivnictví, jejich využití lze nalézt i pro právní dějiny, byt' povětšinou spíše v okrajových tématech. Celkově pak lze shrnout, že při interpretaci soudních rozhodnutí v ortelových knihách apelačního soudu nelze přihlížet pouze $\mathrm{k}$ výroku v dané věci, ale že určující je interpretace i dalších náležitostí, ze kterých se rozhodnutí skládá.

Mgr. Bc. et Bc. Josef Vacek

Právnická fakulta Univerzity Karlovy

vacekj@prf.cuni.cz 